\title{
Sexualitets- och samlevnadsprojektet SamS - utvärdering av ett svenskt kommunprojekt
}

\author{
BRITT-MARIE HALLDÉN \& LARS EDGREN
}

\begin{abstract}
Artikeln handlar om en utvärdering för att förebygga sexuellt riskbeteende bland ungdomar i åldern 14-25 år. Projektet riktades till 17000 ungdomar per år under åren 1989-1994 genom att utbilda de vuxna som i sin yrkesutövning regelbundet möter dessa ungdomar. Vilken betydelse har projektet haft för utvecklingen av tonärsaborter? $\ddot{A}$ r det över huvud taget meningsfullt att försök a förebygga?
\end{abstract}

\section{Bakgrund}

\section{Projektet SamS}

Ökningen av antalet tonårsaborter tillsammans med ökningen av sexuellt överförda sjukdomar ledde till att f.d. Landstinget $i$ Älvsborg avsatte ekonomiska medel för förebyggande insatser (Landstinget i Älvsborg, 1987; 1988). För Borås kommun och pri-

Britt-Marie Halldén är fil.kand., barnmorska och studierektor på Institutionen Vårdhögskolan, Högskolan i Borås.

Lars Edgren är fil.dr och tf. Professor i hälso- och sjukvårdsadministration vid Nordiska hälsovårdshögskolan i Göteborg. märvård har det inneburit att man i samverkan med skola, socialtjänst, föreningsliv och fritidsorganisationer satsat på att utbilda vuxna för att arbeta förebyggande med att påverka ungdomars sexualvanor. Detta resulterade i sexualitets- och samlevnadsprojektetSamS(SamS). Grundidéerna i projektet var att stödja vuxenrollen i mötet med ungdomar, för att de vuxna skulle bli bättre på att utgå från ungdomarnas behov och stärka deras självkänsla. Målet var att minska antalet tonårsaborter och sexuellt överförda sjukdomar. Därtill fanns delmål; att arbeta för en positiv syn på sexualitet och samlevnad, att ge ungdomar möjlighet att lära känna sig själva och sin sexualitet 
samt att stödja vuxna i att utveckla och finna metoder för sexualitets- och samlevnadsundervisning. Vuxna som arbetar inom olika samhällssektorer med ungdomar har engagerats och erbjudits olika utbildningar i sexualitet och samlevnad. Innehållet i utbildningarna var främst metoder och tekniker $i$ syfte att öka de vuxnas kommunikationsfärdigheter i sexualitets- och samlevnadsfrågor för att möta ungdomarnas behov. Utbildningarna har varit sektorövergripande för att stödja intentionen i projektet att bygga upp ett tvärsektoriellt samarbete mellan dem som arbetar med ungdomar inom Borås kommun. Inom ramen för projektet har de vuxna anordnat ett stort antal förebyggande aktiviteter med anknytning till sexualitet ochsamlevnad, t.ex. temadagar, temaveckor, forumteaterföreställningar och föräldramöten.

\section{Interventionsprojekt}

Gotlandsprojektet, en fyraårig försöksverksamhet på 1970-talet rörande sexualitetsoch samlevnadsfrågor inriktades på abortförebyggande åtgärder, vilket resulterade i en minskning av ungdomsaborterna med 30 procent efter två års försöksverksamhet. Samtidigt konstaterades en förskjutning av tonårsgraviditeter och tonårsaborter mot högre åldrar och en minskning av det totala antalet tonårsgraviditeter (Nilsson et al., 1977). Ett projekt för att förebygga human immunodeficiency virus (HIV) omfattade 250000 ungdomar i Stockholms län i åldern 13-20 år fokuserade på ungdomars intresse för relationer och sexualitet. Projektet visade betydelsen av att människor från olika samhällssektorer engagerar sig och att stödjande nätverk växer fram, eftersom det inte finns någon entydig lösning på HIV-problemet (Sundh \& Turunen, 1992).

Utvärderingen av tvånorska ungdomskulturkampanjer identifierade ett ringa antal superaktiva ungdomar som huvudleverantörer av sexuellt överförbara sjukdomar. Av resultatet framgår att ungdom med planer på längre yrkesutbildningar var mera informationssökandeän övriga ungdomar. Konsekvensen var att projektet nått de ungdomar som haft minstanledningattändrabeteende. Att stärka och utveckla ungdomars kommunikationsfärdigheter, knutna till sexualitet och sexuella tema, belystes som viktiga uppgifter i det vidare HIV/aidsförebyggande arbetet (Traeen, 1990). Visser \& Bilsen (1994) har studerat effekter av ett antal sexualitets-och födelsekontrollerande program till ungdomar i Västvärlden. Deras slutsats var bland annat att ungdomars sexuella riskbeteende är svårt att påverka genom dylika program. Författarna rekommenderar att olika determinanter till ungdomars sexuella beteende identifieras för att på ett bättre sätt nå olika målgrupper i riskzonen med olika interventionsprogram.

\section{Faktorer som påverkar ungdomars sexuella beteende}

Till väl kända folkhälsoproblem hos ungdomar världen över hör främst sexuellt överförbara sjukdomar (Std) och tonårsaborter. Dessa rapporteras vanligare hos ungdomar än andra åldersgrupper såväl nationellt som internationellt och är föranledda av ungdomars sexuella beteende (Hedman et al., 1989; Odlind, 1994; Trad, 1994). En mängd 
faktorer finns beskrivna som antas påverka att ungdomar utsätter sig för oskyddade sexuella kontakter som kan leda till sexuellt överförbara sjukdomar och tonårsaborter. Till dessa hör tidig sexualdebut, alkoholkonsumtion, grad av föräldrastöd, kognitiv utveckling och planer på kort yrkesutbildning, egocentrism och självbild (BayneSmith, 1994; Persson \& Jarlbro, 1992a; Persson \& Jarlbro, 1992b; Ruusuvaara, 1983; Santelli \& Beilenson, 1992; Traeen, 1990; West et al., 1993). En negativ självbild beskrivs som en betydelsefull faktor och innebär att ungdomar som inte tycker om sig själva utsätter sig i högre grad för risker än de med positiv självbild. Självbild beskrivs som socialt klassrelateradså till vida att ungdomar från arbetarklassen oftare bär på en mindre positiv självbild än ungdomar från medelklassen. Flickor från skilsmässohem och konfliktfamiljer beskrivs också oftare ha en negativ självbild (Ruusuvaara, 1983). Sexuellt riskbeteende i form av oskyddade sexuella kontakter kan därutöver påverkas av identifierade stressfaktorer som kommunikationssvårigheter i förhållandet till att våga säga nej och att välja partner (Breakwell et al., 1991; Harvey \& Spigner, 1995; Rosenthal et al., 1991). Till denna komplicerade bild hör att de flesta ungdomar som utsätter sig för oskyddade samlag har goda kunskaper om hur man ska skydda sig för att undvika att smittas av Std och bli oplanerat gravida (Persson \& Jarlbro, 1992b; Traeen, 1990).

\section{Utvärdering och bedömningskriterier}

Begreppet utvärdering tolkas vanligen som att värdera en aktivitet genom att bedöma resultatet av densamma vilket kan uttryckas som en noggrann efterhandsbedömning av genomförande, prestationer och utfall av offentlig verksamhet (Franke Wickberg \& Lundgren, 1981; Vedung, 1991). Ofta finns det flera olika syften bakom ett projekt liksom olika förväntningar på en utvärdering. Detta medför att utvärderaren måste överväga vems intressen som ska råda (Sahlin, 1996). Att värdera och bedöma mot vad blir därmed en viktig fråga (Karlsson, 1996). Att basera en utvärdering på verksamhetens mål är ett vanligt sätt och betyder att försöka bestämma hur väl ett projekt uppfyllt de på förhand fastställda målen (Stevrin, 1991). I arbetet med att dokumentera SamS-projektet har frågan om vad projektet ska bedömas gentemot resulterat i nio bedömningskriterier. Dessa kriterier har härletts ur SamS-projektets måldokument (Stevrin, 1991), och stämts av i en förstudie till utvärderingen. Kriterierna följer Abbot och Craigs (1994) sätt att strukturera vad som bör ingå i process- och resultatorienterade utvärderingar av kommunbaserade projekt.

\section{Syfte}

Syftet har varit att genomföra en målbaserad utvärdering av projektet SamS utifrån följande nio bedömningskriterier: kommunikationsformen i projektet, projektets politiska förankring, medvetenhet om pro jektets målsättning, projektets aktualitet, 
projektets tvärsektoriella samarbete, projektets betydelse för pedagogisk utveckling, projektets betydelse för utsatta ungdomar, projektets betydelse ur ett samlevnadsperspektiv och projektets betydelse för utvecklingen av antalet tonårsaborter.

\section{Metod \\ Datainsamling och urval}

Studien har med förstudien inräknad genomförts i fyra steg. I förstudien (steg 1) deltog 17 vuxna som arbetar med ungdomar från olika kommunala sektorer. Dessa lämnade förslag på vad som skulle ingå i utvärderingen, vilket bidrog till att tydliggöra bedömningskriterierna och skapa struktur för datainsamlingen. Utvärderingen genomfördes med en intervjustudie (steg 2) bestående av nio fokuserade gruppintervjuer och två individuella intervjuer (projektledaren samt en kyrklig verksamhetsföreträdare) vilket totalt inbegrep 37 vuxna i fem slumpvis utvalda kommundelar i Borås. Samtliga intervjuer spelades in på band, transkriberades och analyserades utifrån bedömningskriterierna.

Fokuserade gruppintervjuer användes eftersom de är effektiva när man önskar ta del av data av kvalitativ natur. Enligt Kreuger (1990) kännetecknas en fokusgrupp av personer som är utvalda med anledning av att de har vissa karaktäristika gemensamt och kan förmedla erfarenheter i en fokuserad diskussion. Arbetssättet gör att det blir möjligt att jämföra olika gruppers uppfattningar och föreställningar såväl som att beskriva och identifiera variationer (Kreuger, 1990). Samtidigt som frågeområdena varit styrande har intervjuerna genomförts i form av samtal.

Intervjutekniken som använts är inspirerad av socialpsykologisk teori (Ajzen \& Fishbein, 1980; Ajzen, 1988). Detta innebär i korthet, att man använder sig av personers föreställningar och uppfattningar. I detta sammanhang har de vuxnas föreställningar och uppfattningar om projektet varit i fokus för att öka kunskapen om deras erfarenheter av projektet. I bearbetningen av intervjusvaren har Kreugers (1990) beskrivande analysmodell använts. Bearbetningen har genomgått flera faser med utskrivning, läsning, analys och kategorisering i olika temaområden. Efter en första bearbetning återfördes de utskrivna intervjuerna via brev till de som intervjuats för att ge dessa möjligheter till synpunkter och förtydligande av vad som framkommit i intervjuerna.

I steg 3 genomfördes en enkätstudie. Enkäten innehöll frågor om hur olika utbildningsaktiviteter uppfattats, erfarenheter av tvärsektoriellt arbete och hur projektet och olika utbildningsinsatser påverkat sexualitets- och samlevnadsarbetet med ungdomar. Populationen utgjordes av samtliga 191 vuxna i Borås kommun registrerade i SamSutbildningar. Av dessa 191 svarade 149 (78 procent). För databearbetningen har statistikprogrammet EPI-Info använts. Svaren på de öppna frågorna har skrivits ut ordagrant och analyserats. Dessa svar sammanfördes därefter under överordnade beskrivningskategorier och temaområden.

Granskning av tillgänglig statistik (steg 4) har omfattat tonårsaborter (Socialstyrelsen, 1993; 1994; 1995) och använts för att beskriva utvecklingen av antalet tonårsaborter i Borås kommun i jämförelse med Älvsborgs län och Sverige. Ungdomsgrup- 
pens utveckling av tonårsaborter har varit det avgörande sättet att värdera projektets påverkan på den egentliga målgruppen.

\section{Analys}

Analysen av insamlade data som föregått värderingen av projektet följer ett deduktivt angreppssätt. Bedömningskriterierna har härvid fungerat som ett raster och belyst datamaterialet på de områden som varit relevanta för studien. Värderingen grundar sig på en sammanvägning av resultaten från de enskilda intervjuerna, de fokuserade gruppintervjuerna, enkätstudien, granskning av statistik över utvecklingen av tonårsabortersamt forskningsresultat som belyser faktorer som påverkar ungdomars sexuella beteende. Slutligen har en bedömningsskala konstruerats. Denna har två steg: "framgångsrik" respektive "mindre framgångsrik».

\section{Resultat}

Nedan följer en genomgång av de olika utvärderingsaspekterna som följer vart och ett av de nio olika bedömningskriterierna. Varje bedömningskriterium har härvid omvandlats till en specifik frågeställning.

\section{Kommunikationsformen i projektet}

Hur har kommunikationsformen i projektet fungerat?

Utvärderingen av kommunikationsformen baseras på skriftlig dokumentation från projektet, nio fokuserade gruppintervjuer och en individuell intervju med projektle- daren.

Den avsedda kommunikationsformen i projektet för att nå de vuxna som arbetar med ungdomar och därmed indirekt ungdomarna karaktäriseras av ett s.k. "top down" perspektiv (Sabatier, 1986). I genomförandet av projektet skulle arbetet organiseras så att budskapet och därmed målet fördes vidare till ungdomarna genom att utbilda de vuxna. Ledande politiker i Borås hälsopolitiska råd samt en grupp bestående av representanter från fritidsförvaltningen, socialtjänsten, skolan, länssjukvården, primärvården, ekumeniska rådet och föreningsrådet skulle enligt måldokumentet fungera som referensgrupp för projektet. Den avsedda kommunikationsformen har jämförts med den faktiska för att nå målgruppen ungdomar. Figur 1 illustrerar den faktiska kommunikationsformen i projektet.

Arbetet i SamS har präglats av att projektledaren arbetat utifrån sin övertygelse om grundidéerna i projektet, fått stöd i referensgruppen, lyssnat på de problem som funnits ute i verksamheterna för att därefter starta och stödja olika aktiviteter. Projektledare och utbildade vuxna har växelvis påverkat varandra. Referensgruppen har kommit att fungera som en stödgrupp àt projektledaren. Resultaten visar att projektet främst blivit ett projekt för skolan där man uppnått störst påverkan på högstadieskolorna i sju av kommunens tio kommundelar. Därutöver visar resultaten att de projektdeltagare som arbetar på barnmorskemottagningar, fritidsgårdar, skolor och inom socialtjänst givits förutsättningar för att samverka och arbeta för att förebygga tonårsaborter och sexuellt överförda sjukdomar. 
Figur 1

Projektets kommunikationsform.

\begin{tabular}{ccc} 
Aktör & Kommunikationsriktning & Kommunikation \\
\hline Referensgrupp & & Stöder projektledaren \\
Projektledaren & $\Uparrow$ & Tolkar projektets grundidéer \\
Vuxna i utbildning & $\Uparrow$ & Uppfattar problem i verksamheten
\end{tabular}

Den faktiska kommunikationsformen visar således på en deltagarstyrd kommunikationsform till skillnad från en målstyrd. Den faktiska kommunikationsformen kan också uttryckas som en demokratisk modell och ett avståndstagande från det målstyrda "top-down" perspektivet. En konsekvens av den faktiska kommunikationsformen är att de hälsopolitiska målen och det uttalade målet och budskapet att minska antalet tonårsaborter och sexuelltöverförda sjukdomar i projektet inte varit styrande för organisation och genomförande. Följande citat illustrerar vad de flesta deltagarna uttryckt:

Måletär attskapa litenärmare relationer mellan människor. Det är mycket mer de dagliga relationerna det handlar om, än sex och samlevnad (lärare).

Projektet bedöms ha varit mindre framgångsrikt med hänsyn till kommunikationsformen. Det uttalade målet i projektet har inte varit styrande när olika aktiviteter startats upp i ungdomarnas närmiljö.

\section{Projektets politiska förankring}

Har den politiska förankringen varit betydelsefull?
Utvärderingen av den politiska förankringen baseras på nio fokuserade gruppintervjuer och två individuella intervjuer.

Referensgruppen poängterade betydelsen av att projektet varit politiskt förankrat och pekade på att ledande politiker i Borås hälsopolitiska råd ingått samt att de haft en stödjande funktion. Följande citat belyser referensgruppens erfarenhet:

Det är oerhört viktigt för allt förebyggande arbete att det är politiskt förankrat och att hälsopolitiska rådet nu består utav politiker som är i ledande ställning för kommunen. Det är inte inom hälso- och sjukvården som det förebyggande arbetet behöver bedrivas i huvudsak utan i samhället där människorna finns (hälsoplanerare).

En av anledningarna till att förankra projektet hos ledande kommunala politiker var att det inte ansetts lika självklart att det förebyggande arbetet skulle bedrivas i kommunal regi. Arbetssättet beskrevs som "mödosamt och måste föras enträget». Speciellt lärargruppen tydliggjorde att den politiska förankringen varit en förutsättning för deras engagemang eftersom ekonomiska medel kunnat avsättas för kostnader för vikarier i samband med deras deltagande i SamSutbildningarna. 
Projektet bedöms ha varit framgångsrikt i detta avseende, eftersom det varit politiskt förankrat och denna förankring varit nödvändig för genomförandet. Medvetenheten om det förebyggande arbetets betydelse anses ha ökat hos ledande politiker i Borås Hälsopolitiska Råd, eftersom de varit involverade i genomförande av det kommunbaserade arbetet och ekonomiska medel därför kunnat avsättas för det förebyggande arbetet.

\section{Medvetenhet om projektets målsättning}

HarverksamhetsföreträdareochSamS-utbildade varit medvetna om målet?

Utvärderingen om medvetenhet om projektets målsättning baseras på nio fokuserade gruppintervjuer och två individuella intervjuer samt enkätstudien.

Medvetenheten gäller främst projektets delmål att arbeta för en öppen och positiv syn på sexualitet och samlevnad. Målet att minska antalet tonårsaborter och att förebygga sexuellt överförda sjukdomar råder stor oklarhet om. Endast någon enstaka person framför funderingar på om det inte från början varit meningen att arbetet i projektet skulle påverka abortantal och Stdsjukdomar.

Deltagarna i projektet relaterar således inte sitt arbete till ett förebyggande arbete för att minska antalet tonårsaborter och sexuelltöverfördasjukdomar utan till grundidéerna om att stödja vuxenrollen i mötet med ungdomar. Här finns en diskrepans mellan f.d. Landstinget i Älvsborgs ursprungliga mål, projektets mål och behovet av att arbeta för goda mellanmänskliga relationer ute $\mathrm{i}$ verksamheterna. Delmålet i projektet att ge ungdomar möjligheter att lära känna sig själva och sin sexualitet är endast framträdande på en högstadieskola med erfarenhet av tio års arbete med sexualitets- och samlevnadsfrågor. Ett annat delmål i projektet, att utveckla och finna metoder för sexualitets- och samlevnadsundervisningen har däremot betonats.

Projektet bedöms ha varit mindre framgångsrikt att sprida kunskap om mål och delmål, eftersom de flesta verksamhetsföreträdarna och utbildade vuxna inte kunnat ge uttryck för målet med projektet. De aktiviteter som startats i genomförandet av projektet har varit inriktade på att tillgodose ungdomars behov av vuxenrelationer, som vanligtvis inte hör ihop med sexualitet och riskbeteende utan mera handlar om att leva tillsammans.

\section{Projektets aktualitet}

Finnsdetenöverensstämmelse mellangrundidéerna i projektet och olika forskningsresultat som belyser faktorer som påverkar ungdomars sexuella riskbeteende?

Utvärderingen av projektets aktualitet baseras på olika forskningsresultat om vad som påverkar ungdomars sexuella beteende.

Projektets aktualitet handlar om hur väl dess grundidéer överensstämmer med aktuell forskning om vad som kan påverka ungdomars sexuella vanor. Grundidéeerna har varit att stödja vuxenrollen i mötet med ungdomarna på sin väg att bli vuxna och att stärka deras självkänsla. Sammanfattningsvis kan sägas att undersökta forskningsstudier inte ger några entydiga resultat om vad som påverkar ungdomars sexuella beteende. 
Projektet bedöms som framgångsrikt eftersom att det finns en överensstämmelse mellan projektets grundidéer som främst handlar om att stödja vuxenrollen i mötet med ungdomar samt att stärka ungdomarnas självkänsla. Bedömningen bygger på tillgängliga forskningsresultat som visar på ungdomars behov av vuxenstöd och en stärkt självbild (Bayne-Smith, 1994; Persson \& Jarlbro, 1992b; Ruusuvaara, 1983; Santelli \& Beilenson, 1992; Traeen, 1990; West et al., 1993) för att de inte ska utsätta sig för sexuellt riskbeteende.

\section{Projektets tvärsektoriella samarbete}

Har ett tvärsektoriellt samarbete uppnåtts $i$ arbetet med sexualitets- och samlevnadsfrägor ute i kommundelarna?

Utvärderingen av det tvärsektoriella samarbetet baseras på den skriftliga dokumentationen av projektet, nio fokuserade gruppintervjuer, två individuella intervjuer samt enkätstudien.

Samarbete skulle ske mellan landsting, primärvård, kommun, frivilliga och hälsovårdsinriktade organisationer. Den tidigare utvärderingen av SamS (Blank, 1991) rekommenderade att det tvärsektoriella arbetet skulle stabiliseras för att projektet skulle ha möjlighet att fortleva. Resultaten visar att det från början funnits en tvärsektoriell ansats men att projektet efter hand alltmer kom att drivas av enbart skolan. Följande citat förmedlar erfarenheten:

Vad jag själv kände var att vi står liksom bara och stampar. Vi visade någon film för ungdomarna och hade något föredrag. Det var svårt att hitta någonting som vi ville tillsammans... Jag tror inte att det går att hitta en gemensam profil eftersom vi är olika som människor med olika ideologier eller olika livsåskådning (präst).

Det är mestadels lärare som deltagit i olika utbildningsaktiviteter och där det förekommer samarbete är det främst mellan lärare och fritidsledare som arbetar på skolorna. Det är naturligtvis så att lärarna till antalet är en stor grupp och att det är på skolorna som huvuddelen av ungdomarna befinner sig.

Projektet bedöms ha varit mindre framgångsrikt i detta avseende eftersom ett tvärsektoriellt samarbete ute i kommundelarna inte uppnåtts, vilket bedöms påverka projektets möjligheter att fortleva i framtiden.

\section{Projektets betydelse för pedagogisk utveckling}

Har SamS-utbildningarna varit framgångsrika ur ett pedagogiskt perspektiv?

Utvärderingen av projektets betydelse för pedagogisk utveckling baseras främst på enkätstudien.

Utbildningarnafår ettöversvallande positivt betyg, vilket överensstämmer med den tidigare utvärderingen (Blank, 1991). Metoderna i olika utbildningsaktiviteter uppfattas som positiva, inspirerande och utvecklande med möjligheter till ett ökat kontaktnät mellan personal som arbetar med ungdom. De tekniker och metoder, som funnits i den pedagogiska ansatsen har upplevts som speciellt värdefulla. Av resultatet framgår att medverkan i utbildning påverkat det egna arbetet motsvarande 30 procent (44 personer) i hög utsträckning, 44 procent 
(65 personer) i viss utsträckning, 15 procent (23 personer) i mindre utsträckning och 4 procent ( 6 personer) inte alls. Deltagarnas arbete med samlevnadsfrågor har kommenterats och kategoriserats i temaområden samt uppges efter olika utbildningsaktiviteter ha påverkat:

- metoder i undervisningen (4l st. kommentarer),

- bemötandet av elever (19 st. kommentarer),

- olika aktiviteter (14 st. kommentarer),

- den egna personen, kvinno- respektive manssynen (11 st. kommentarer),

- samarbetet med andra (4 st. kommentarer).

En lärarekallar pedagogiken involveringspedagogik. Följande uttalande bidrar till bedömningen av utbildningarna och sammanfattar mångas uppfattning:

Målet är att genom involvering och engagemang skapa respekt och förståelse och samförstånd genom att se varandras olikheter och likheter och skapa ett bra förhållande mellan elev-elev och ett öppet och ärligt förhållande mellan lärare-elev (lärare).

Ur ett pedagogiskt perspektiv bedöms utbildningarna ha varit framgångsrika. På frågan om presenterade idéer och metoder för samlevnadsutbildning varit användbara svarar 48 procent i hög utsträckning, 40 procent svarar i viss utsträckning och 7 procent i liten utsträckning. Till de idéer och metoder som kommenterats som användbara är i angiven ordning värderingsövningar, forumspel, bildövningar, drama, lekar, samarbetsövningar och förhållningssätt i samtal. Vissa pedagogiska tekniker har med fördel även kunnat användasinomandraämnesområden som svenska, samt samhällsvetenskapligtoch naturvetenskapligt orienterade ämnen.

\section{Projektets betydelse för utsatta ungdomar}

Har SamS-utbildade efter utbildningen arbetat med speciella insatser för utsatta ungdo mar som $i$ sin förlängning kan påverka ung domars sexuella riskbeteende?

Utvärderingen av projektets betydelse för utsatta ungdomar baseras främst på enkätstudien och en fokuserad gruppintervju med fritidsledare.

Av enkätstudien framgår att 70 procent av deltagarna i utbildningarna inte tar upp problem kring sexuellt riskbeteende mer efter genomgången utbildning än tidigare i sin undervisning. Utbildningarna har inte resulterat i speciella insatser till utsatta ungdomar förutom på en högstadieskola som byggt upp ett faddersystem för invandrarungdom. Däremot har fritidsledare, skolsköterskor och kuratorer beskrivit sin relationsroll som integrerad i det dagliga mötet med ungdomar. Detta tyder snarare på ett förhållningssätt i yrkesprofessionen än ett resultat avSamS-utbildningarna. Iden fokuserade gruppintervjun med fritidsledare framkom att ca 10 procent av samtliga ungdomar som söker sig till fritidsgårdarna inte orkar med skolan och dess krav. Följande citat förmedlar erfarenheterna:

Vi har den här gruppen som inte är intresserad
av den reglerade verksamheten ... Det är ungdo-
mar som inte orkat med skolan på samma sätt.
Dom är då överrepresenterade på fritidsgårdar.
Det är enda stället i hela samhället där gruppen
har en talan ... Den här gruppen klarar inte för-
eningslivet av. Det gäller t.ex. tjejer som riske
rar att bli mammor tidigt eller alldeles för tidigt 
(fritidsledare).

Resultaten tyder på att projektet inte nått den mest behövande gruppen, de utsatta ungdomarna. Utbildningarna har inte resulterat i speciella insatser till utsatta ungdomar. Däremot har fritidsverksamheten stått för speciella insatser för ungdomar med sociala problem.

Utvärderingen visar med hänsyn tagen till utbildningarnas betydelse för utsatta ungdomar att projektet varit mindre framgångsrikt i att stimulera till speciella insatser, som i sin förlängning kan påverka utsatta ungdomars sexuella beteende.

\section{Projektets betydelse ur ett samlevnadsperspektiv}

Har projektet varit betydelsefullt ur ett samlevnadsperspektiv?

Utvärderingen av projektets betydelse ur ett samlevnadsperspektiv baseras på resultatet av litteraturgenomgången och resultaten från samtliga intervjuer.

Forskningsresultat visar att ungdomar vanligtvis har goda kunskaper om sexuellt överförda sjukdomar och hur man ska skydda sig mot hälsorisker (Persson \& Jarlbro, 1992b; Traeen, 1990). Denna kunskap gör att man kan förutsätta att ungdomar har mindre behov av faktakunskaper än att arbeta med relationer och förhållningssätt mellan människor. Resultaten av intervjuerna visar att mellanmänskliga relationer och samlevnad dominerat olika aktiviteter riktade till ungdomarna. Det har också funnits en medvetenhet om ungdomars och inte minst vuxnas behov av betydelsefulla möten. Följande citat får illustrera den dominerande bilden:

Vid ett verkligt möte snuddar du vid en annan människa och du tar del av en annan människas tankar och värderingar. Du lär dig något om dig själv och får större insikt om andra människors tankar och behov. Som vuxen ska jag skapa förutsättningar för att ett möte ska kunna ske mellan ibland mig själv och barnet och ibland mellan barn och barn. Har jag som vuxen insett att jag i mötet med barnen, ungdomarna, kan lära mig något om mig själv så är mina möjligheter att fungera som en bra vuxenförebild stor (projektledare).

Utvärderingen visar att projektet varit framgångsrikt ur ett samlevnadsperspektiv eftersom ungdomars behov av »betydelsefulla möten" med vuxna och mellanmänskliga relationer i form av en ökad kommunikation varit tongivande inslag i olika utbildningsaktiviteter till ungdomarna.

\section{Projektets betydelse för utvecklingen av antalet tonårsaborter}

Har projektet varit framgaingsrikt $i$ att minska antalet tonairsaborter och sexuellt överförbara sjukdomar?

Utvärderingen av projektets betydelse för utvecklingen av antalet tonårsaborter och sexuellt överförbara sjukdomar baseras på tillgänglig statistik.

Det finns begränsande möjligheter att värdera projektets betydelse för utvecklingen av antalet aborter och utvecklingen av sexuellt överförda sjukdomar. Detta p g a att utvecklingen är beroende av många faktorer i samhället. Projektet ingår i ett system av olika åtgärder riktade mot att påverka ung- 
domars hälsa, varför det inte går att se projektet som en isolerad företeelse. Resultatet visar på en ökning av frekvensen tonårsaborter under projektperioden med 20 procent under åren 1989-1994, från 17,1 till 20,5 per 1000 kvinnor i Borås kommun. Motsvarande siffror för f.d. Älvsborgs län och Sverige visar en minskning av antalet tonårsaborter med 31 procent respektive 28 procent (Socialstyrelsen, 1993; 1994; 1995).

Vad gäller utvecklingen av frekvensen sexuellt överförbara sjukdomar hos tonåringar finns inte samma möjligheter till jämförelse över tid och mellan olika områden eller länder. Någon registrering av antalet sexuellt överförbara sjukdomar för tonåringar görs inte. Den tillgängliga statistiken för Älvsborgs län visar totalt på en betydande nedgång vad gäller sexuellt överför- bara sjukdomar från år 1989 till 1994(Källa: Smittskyddsenheten i f.d. Älvsborgs län).

Utvärderingen av projektet visar att det varit mindre framgångsrikt eller rent $\mathrm{av}$ misslyckats i att minska antalet tonårsaborter. Resultatet från Gotland pekade på en minskning med 30 procent av tonårsaborterna under en tvåårsperiod, från 29 tonårsaborter till 20 per 1000 kvinnor (Nilsson et al., 1977). Resultatet av granskningen av tonårsaborter i Borås kommun visar på en ökning av antalet aborter under projektperioden. En ökning som avviker markant i förhållande till f.d. Älvsborgs län och Sverige som helhet.

\section{Värderingen i sammanfattning}

Tabell 1 sammanfattar utvärderingsresultaten.

Tabell 1

Utvärderingsresultaten i sammanfattning

Bedömningskriterier för SamS

Bedömningsskala Framgångsrik Mindre framgångsrik

Kommunikationsformen i projektet

Projektets politiska förankring

Medvetenhet om projektets målsättning

Projektets aktualitet

Projektets tvärsektoriella samarbete

Projektets betydelse för pedagogisk utveckling

Projektets betydelse för utsatta ungdomar

Projektets betydelse ur ett samlevnadsperspektiv

Projektets betydelse för utvecklingen av antalet tonårsaborter
$X$

$x$

$x$

$x$

$x$

$x$

$X$

$x$
X 


\section{Diskussion och slutsatser}

Utvärderingen ger vid handen att möjligheten att påverka utvecklingen av tonårsaborter och sexuellt överförda sjukdomar är beroende av tydliga mål, central samordning och politiskt stöd.

Andra studier (Grueen et al. ,1991; Males, 1993; Persson \& Jarlbro, 1992b; Santelli \& Beilenson, 1992; Traeen, 1990) visar att det är redan utsatta ungdomsgrupper som utsätter sig för sexuella hälsorisker. Visser \& Bilsen (1994), som undersökt effekten av olika utbildningsprogram till ungdomar i västvärlden, konstaterar att olika determinanter till sexuelltriskbeteendebör analyseras och definieras för att anpassa insatser till utvecklingen av interventionsprogram till ungdomar. Traeen (1990) identifierar gruppen ungdomar med planer på korta yrkesutbildningar i behov av speciell uppmärksamhet. Han poängterade vikten av att stärka och utveckla ungdomarnas kommunikationsfärdigheter knutna till sexualitet och sexuella teman. Dessa erfarenheter har man, i SamS-projektets utbildningar för olika personalkategorier, använt och arbetat efter, för att utveckla pedagogiska metoder och tekniker i sexualitets- och samlevnadsundervisningen. Mest framträdande i utvärderingen är att SamS-utbildade och verksamhetsföreträdare ordnat aktivitets- och temadagar i sexualitet- och samlevnad med tyngdpunkt på samlevnad. Den vardagsnära dialogens betydelse för ungdomarna var inte framträdande i vare sig intervju- eller enkätstudien varför det är ytterst tveksamt om man når den mest behövande ungdomsgruppen, de som utsätter sig för sexuellt riskbeteende.

Det har emellertid funnits en medveten och intressant strategi $i$ genomförandet av SamS-projektet. Grundidéerna i projektet har varit att stödja vuxenrollen för att de vuxna ska kunna bidra till att stärka ungdomarnas självkänsla på sin väg att bli vuxna. Utvärderingen bekräftar tidigareforskningsresultat, $d \mathrm{v}$ s att utsatta ungdomar är överrepresenterade bland ungdomar som utsätter sig för hälsorisker. Dehar därför speciella behov av insatser. Speciella behov eftersom de har de ekonomiskt sämsta förutsättningarna, dålig självkänsla och inte sällan bär på negativa upplevelser av uppväxt och skolutbildning. De har dessutom begränsade möjligheter att få ett utvecklande arbete i framtiden. I detta perspektiv uppfattas det närmast som utopiskt av fritidsledarna att de ska kunna hjälpa dem att stärka deras självkänsla så att de inte utsätter sig för onödiga risker.

Den övergripande strategin i SamS-projektet kan ifrågasättas. Det ingår inte i den målbaserade utvärderingen att ifrågasätta målen för den verksamhet som utvärderas. Men frågan måste väckas om projektet definierat den indirekta målgruppen ungdomar på ett lämpligt sätt. Eftersom projektets indirekta målgrupp varit alla ungdomar som vid tillfället för projektets genomförande varit bosatta i Borås fokuserades en hel del resurser på de ungdomar som redan var väl upplysta och inte tillhörde någon riskgrupp. Denna grupp riskerar bli informationstrött när den gång efter annan får information som inte uppfattas angelägen. Om projektets mål att minska antalet tonårsaborter

Halldén \& Edgren: Sexualitets- och samlevnadsprojektet SamS 
och sexuellt överförbara sjukdomar tidigt hade identifierat den mest behövande ungdomsgruppen, den grupp som utsätter sig för sexuellt riskbeteende och var den gruppen kan nås, på fritidsgårdarna, hade projektresurserna kunnat riktas mot fritidsledarna för att stödja dem i att hjälpa och stärka självkänslan hos den aktuella ungdomsgruppen. Frågan kvarstår beträffande på vilket sätt utsatta ungdomars självkänsla kan stärkas så att de inte utsätter sig för onödiga risker? Som dagens samhälle ser ut för närvarande är det uppenbart att deras behov och situation skiljer sig från ungdomars behov och situation $i$ allmänhet, eftersom deras möjligheter är starkt begränsade. Fritidsledarna har bidragit till att skapa underlag för denna slutsats.

Projektet har således gett lärarna nya pedagogiska färdigheter men inte lyckats påverka ungdomars sexuella hälsa.

\section{Litteratur}

Abbot, D., \& Craigh, B. (1994) „How to evaluate your health community programs». Paper no 2 . Research and Evaluation in Community Health Series, South Australian Community Health Research Unit. Adelaide: Flinders Press.

Ajzen, I., \& Fishbein, M. (1980) Understanding Attitudes and Predicting Social Behavior. New Jersey: Prentice-Hall, Englewood-Cliffs.

Ajzen, I. (1988) Attitudes, Personality and Behaivor. Buckingham: Open University Press.

Bayne Smith, M. (1994) "Teen incentives program: Evaluation of a health promotion model for adolescent pregnancy prevention". Journal of Health Education 25, 24-29.

Blank, P. (1991) Växt några centimeter som människa. En utvärdering av SamS-projektet $i$ Boräs 1991. Borås: Borås Hälsopolitiska Råd.

Breakwell, G., Fife-Schaw, C., \& Clayden, K. (1991) "Risk-taking, control over partner choice and intended use of condoms by virgins". Journal of Community and Applied Social Psychology, 1 (2), 173-187.

Franke Wikberg, S., \& Lundgren, U. P. (1981) Att värdera utbildning. Del 2. Hälsingborg: Wahlström \& Widstrand.

Gruen, S., Hayes, E., \& Fritsch- deBruyn, R. (1991) "Setting Up a School-Based Sexual Education Program to Help Prevent Aids and Other Sexu- ally Transmitted Diseases». Nurse Practitioner, 16 (8): 47-52.

Harvey, S., \& Spigner, C. (1995) „Factors associated with sexual behavior among adolescents: A multivariate analysisu. Adolescence 30: 253-264.

Hedman, P., Bergström S., Poutiainen, R., \& Claeson, M., et al. (1989) Health for all. Swedish experiences and resources. Uppsala: Indevelop.

Karlsson, O. (1996) Att utvärdera mot vad? Stockholm: HLS Förlag.

Kreueger, R. (1990) Focus Groups. A pratical guide for applied research. London: Sage Publications.

Landstinget i Älvsborg (1987) Hälsopolitiskt program. Vänersborg: Hälso- och sjukvårdsavdelningen. Samhällsmedicinska enheten.

Landstinget i Älvsborg (1988) Förslag till fördelning av anslaget om 7 miljoner för ätgärder mot sexuellt överförbara sjukdomar. Vänersborg: Hälsooch sjukvårdsavdelningen. D:nr 1639/88.

Males, M. (1993) "School-age Pregnancy: Why hasn't Prevention Workedı? Journal of School Health, 63, 429-432.

Nilsson, A., Olsson, H., \& Sundström, K. (1977) Försöksverksamhet med sex och samlevnad på Gotland 1973-1976. Stockholm: Socialstyrelsens nämnd för hälsoupplysning.

Odlind, V. (1994) Abort i Sverige. Rapport nr 27. Arbets-och referensgrupp ad hoc för abortvård. 
Linköping: Institutionen för obstetrik och gynekologi, Svensk förening för obstetrik och gynekologi.

Persson, E., \& Jarlbro, G. (1992a) »Tidig sexualdebut indikator på sexuellt riskbeteende". Läkartidningen, 15, 1276-1277.

Persson, E., \& Jarlbro, G. (1992b) "Sexual behavior among youth clinic visitors in Sweden: knowledge and experiences in an HIV perspectiver. Genitourin, 68, 26-31.

Rosenthal, L., Moore, S., \& Flynn, I. (1991) "Adolescent self-efficacy, selfesteem and sexual risktaking». Journal of Community and Applied Social Psychology, 1(2), 77-88.

Ruusuvaara, L. R. (1983) Teenage abortions: family background, sexual experience and contraceptive use. Helsingfors: Medicinska Fakulteten.

Sahlin, I. (red.) (1996) Projektets paradoxer. Lund: Studentlitteratur.

Sabatier, P. (1986) "Top-Down and Bottom-Up Approaches to Implementation. Research: A Critical Analysis andSuggestedSynthesis". Journal of Public Policy, 6:21-48.

Santelli, J., \& Beilenson, P. (1992) „Risk Factors for Adolescent Sexual Behavior, Fertility and Sexually Transmitted Diseasesu. Journal of School Health, 62, 271-279.
Socialstyrelsen (1993) Aborter 1992. Socialstyrelsens statistik. Socialstyrelsen, Epidemiologiskt Centrum. Stockholm: Statistiska centralbyrån.

Socialstyrelsen (1994) Aborter 1993. Socialstyrelsens statistik. Socialstyrelsen, Epidemiologiskt Centrum. Stockholm: Statistiska centralbyrån.

Socialstyrelsen (1995) Aborter 1994. Socialstyrelsens statistik. Socialstyrelsen, Epidemiologiskt Centrum. Stockholm: Statistiska centralbyrån.

Stevrin, P. (1991) Utvärdering för förändring. Lund: Studentlitteratur.

Sundh, K., \& Turunen, P. (1992) Social mobilisering. Om samhällsarbete $i$ Sverige. Stockholm: Allmänna Förlaget.

Trad, P. (1994) "A developmental model for risk avoidance in adolescents confronting Aids". $E d u$ cation and Prevention, 6, 322-338.

Traeen, B. (1990) Ungdomsseksualitet i Aids-tider. Oslo: Statens institutt for folkehelse.

Vedung, E. (1991) Utvärdering i politik och förvaltning. Lund: Studentlitteratur.

Visser, A., \& Bilsen, P. (1994) "Effectiveness of sex education provided to adolescents". Patient Education and Counseling, 23, 147-160.

West, P., Wight, D., \& Macintyre, S. (1993) »Heterosexual behaviour of 18-year-olds in Glasgow areaw. Journal of Adolescense, 16, 367-396.

\section{Summary The SamS sexuality and relationship project: Evaluation of a Swedish municipal project}

The sexuality and relationship project "SamS" was initiated in the municipality of Borås, Sweden, in 1989 and was completed in 1994. The goals have been to work for positive and open-mindedattitudes towards sexuality and relationship and to prevent sexually transmitted diseases (STD) and unintended pregnancies. The project focu- sed on education of persons from different fields of action, providing different activities to about 17,000 young people annually. The aim of this study has been retrospectively to evaluate the SamS project. Data were collected from eight focus-groups and individual interviews with 33 field-workers. A questionnaire included 149 persons who 
were educated in the SamS project.

The result showed that the project, initially community-run, after a short period became a responsibility solely for the school in the community and that the direct support of the local politicians was critical for the survival of the project. The fieldworkers were aware of the basic ideas of the project, but these goals did not guide the project. These basic ideas correspond well with research results about teenagers' sexual behaviour. The project was successful from a pedagogic and a relationship per- spective. From a public health perspective, it was less successful because the participants did not give priority to work with teenagers' risk-assuming behaviour to reduce abortion rates. The abortion rates show an increase during the project period. The abortion rates in the municipality of Borås did not differ from Swedish municipalities in general. This evaluation concludes with an alternative way about how to reduce teenagers' abortion rates as well as the rates of sexually transmitted diseases. 